\title{
From OEM Supplier To A Global Leading Company
}

Wei-Li Wu, Chien Hsin University of Science and Technology, Taiwan

Yi-Chih Lee, Chien Hsin University of Science and Technology, Taiwan

\begin{abstract}
Firms in developing countries generally have lower technological and marketing capabilities compared to firms in developed countries. Joining OEM alliances can help firms with fewer capabilities to learn from their partners and then upgrade their technological capabilities. In this kind of scenario, learning firms in OEM alliances are usually from developing countries, and they play the role of suppliers; on the other hand, teaching firms are usually from developed countries and play the role of buyers. Although OEM alliances provide a platform for acquiring, transferring and creating knowledge, few suppliers can sufficiently upgrade their technological capabilities to reach a higher level and develop marketing capabilities in order to complete in the global market. Therefore, it is an important issue to know how an OEM supplier from developing countries can become a leading firm in the global market. In this study, we choose Giant Bicycles to explore this issue. We conduct a case study to explore the growth of Giant Bicycles from an OEM supplier to a leading company in the bicycle industry.
\end{abstract}

Keywords: OEM; Giant Bicycles; Global Strategy

\section{INTRODUCTION}

$\mathrm{n}$ the economic system of globalization, in order to focus resources on value chain activities with high additional value (such as R\&D and marketing), multi-national enterprises of developed countries tend to outsource production to developing countries that have a lower labor cost. This practice is called original equipment manufacturer (OEM). Generally speaking, OEM buyers are usually from multi-national enterprises in developed countries, and OEM suppliers are from developing countries. The cooperative model of OEM has different strategic meanings to buyers and sellers. For the buyers of OEM, reduction of the product cost is the main factor. When the suppliers lose the advantage of labor cost due to economic development in their countries, these buyers will search for OEM in other countries that have a cheap labor cost.

For the suppliers in developing countries, OEM plays a totally different role. We classify OEM suppliers into three types. First, for most of suppliers, the acquisition of foreign OEM orders usually means they will have excellent financial performance in the short term. However, if these suppliers only rely on cost advantage, they will easily lose orders from the buyers when developing countries with a better cost advantage enter the labor market. Hence, suppliers will have to either move their plants to countries with lower labor costs or stop their operations. Secondly, for a small number of suppliers, OEM forms an excellent learning platform. In order to meet basic quality requirement, in the OEM process, buyers in developed countries will conduct technological transfer related to product knowledge to the suppliers, which then have the opportunity to learn the basic manufacturing techniques of the industry. Subsequently, according to the product knowledge obtained from the OEM process, suppliers invest in R\&D and enhance the core technology of the product. Sometimes their technique and capacity can be superior to that of the OEM buyers that taught them the basic product knowledge. Thirdly, for a very few number of suppliers, they can cultivate their core capacity of product manufacturing through the OEM process, and also develop their own brands instead of simply producing products for the buyers.

Generally speaking, for suppliers, having brands in the global market should be a critical factor of sustainable operations. However, numerous challenges can be encountered during the process. For instance, the 
suppliers must invest in more funds in uncertain R\&D, and they will encounter the threats of losing the buyers' orders and unfamiliar marketing. Thus, OEM suppliers in developing countries tend to fail when developing their own brands. In this study, we will analyze Giant Bicycles, which has created a successful brand. Giant is a family enterprise founded in Taiwan in 1972. In early times, it mainly relied on manufacturing. However, through the use of prominent global strategies, Giant has become one of the leading bicycle suppliers in the world. We will find how Giant enhanced its core capacity through the use of precise global strategies and arrangements at different stages, which could serve as a reference for the OEM suppliers in developing countries.

\section{GIANT}

In 1972, Giant was founded in a small town in central Taiwan. In early times, it was a small-scale family enterprise and was not familiar with bicycle manufacturing techniques. However, forty years later, Giant has become one of leading bicycle suppliers in the world, with a global business volume reaching 54 billion dollars. It has more than 12,000 retail partners around the world and has received numerous product design awards. Giant is the best example of an OEM supplier in a developing country transforming into a brand name company. In the beginning, it learned manufacturing techniques through OEM cooperation, while at later stages it developed its prominent core capacity and competitive advantages. At different stages, Giant gradually constructed its core capacity through strategic alliances and global arrangements. This study suggests that Giant developed its core capacities by integrating internal and external resources, and enhanced this capacity through global arrangements.

\section{CASE ANALYSIS}

Using interviews, corporate annual reports, and secondary reports (Lin, 2008; Giant Bicycles website, 2014), this study will analyze the core capacity development of Giant. Table 1 shows the important events since the foundation of Giant and the strategies of growth. We will divide the growth of Giant into four stages: the foundation stage, the technical development stage, the growth stage, and the brand growth stage. The content is shown below.

\section{Foundation Stage}

At the beginning, Giant was unfamiliar with bicycle manufacturing techniques, and it could only imitate and learn from Japan. Through entering an OEM agreement with Schwinn, the leading bicycle enterprise in the U.S. at the time, it obtained knowledge transfer and enhanced its bicycle manufacturing techniques.

\section{Technical Development Stage}

With the technological base from the foundation stage, Giant combined the R\&D capacity of external academic institutes (the Industrial Technology Research Institute of Taiwan), developed a carbon fiber bicycle, and applied new techniques using composite materials to bicycle manufacturing. Giant was aware that China had opened the labor market, and that Schwinn could withdraw its orders at any time; therefore, Giant started promoting its own brand and selling the brand in Europe and America.

\section{Growth Stage}

At this stage Giant possessed the differential $R \& D$ and manufacturing capacities needed to support development of its brand. During this time Giant expanded to China, taking into consideration of the dual role of China as the world market and the world factory. In Taiwan, Giant opened life experience stores under direct management, thus reaching out to its customers, enhancing its service, and listening to customers.

\section{Brand Growth Stage}

In regards to the price competition in newly industrialized countries, Giant formed industrial alliances with its main rivals and component suppliers in Taiwan, thereby upgrading the bicycle industry in Taiwan and avoiding price competitions with other countries. In addition, it sponsored important bicycle competitions to increase its brand reputation and product quality. Finally, it created a bicycle-friendly environment in Taiwan. 
Table 1: Giant Bicycle's Global Strategy

\begin{tabular}{|c|c|c|c|}
\hline & Year & Events & \begin{tabular}{|l} 
Strategies of Growth \\
\end{tabular} \\
\hline \multirow{2}{*}{$\begin{array}{l}\text { Foundation } \\
\text { stage } \\
1972-1984\end{array}$} & 1972 & $\begin{array}{l}\text { Founded in Taichung County, Taiwan, } \\
\text { with a capitalization of } 4 \text { million dollars } \\
\text { and more than } 30 \text { employees. }\end{array}$ & $\begin{array}{l}\text { It learned basic bicycle manufacturing techniques } \\
\text { from Japan. } \\
\text { Based on industrial standards and Japanese } \\
\text { specifications, it convinced its partners and } \\
\text { component suppliers to upgrade the product quality. }\end{array}$ \\
\hline & 1978 & $\begin{array}{l}\text { Schwinn, the leading bicycle company in } \\
\text { the U.S., started procurements from } \\
\text { Giant. }\end{array}$ & $\begin{array}{l}\text { It enhanced its bicycle manufacturing techniques } \\
\text { through the manufacturing process for Schwinn. } \\
\text { It started marketing the Giant brand in Taiwan. }\end{array}$ \\
\hline \multirow{4}{*}{$\begin{array}{l}\text { Technical } \\
\text { development } \\
\text { stage }\end{array}$} & 1985 & $\begin{array}{l}\text { Signed contracts with the Industrial } \\
\text { Technology Research Institute to develop } \\
\text { carbon fiber bicycles. }\end{array}$ & $\begin{array}{l}\text { By cooperation with external national } R \& D \text { institutes, } \\
\text { it constructed its core technical capacity. }\end{array}$ \\
\hline & 1986 & $\begin{array}{l}\text { China opened its low-cost labor market } \\
\text { and buyers began turning to China. }\end{array}$ & $\begin{array}{l}\text { It started constructing marketing networks for its } \\
\text { brand. }\end{array}$ \\
\hline & & Founded branches in Europe and the U.S. & \\
\hline & 1991 & $\begin{array}{l}\text { Terminated the OEM relationship with its } \\
\text { main buyer, Schwinn. }\end{array}$ & $\begin{array}{l}\text { Development turned from OEM manufacturing to } \\
\text { brand development. }\end{array}$ \\
\hline \multirow{5}{*}{$\begin{array}{l}\text { Growth stage } \\
1992-2001\end{array}$} & 1992 & $\begin{array}{l}\text { Successful development of one-piece } \\
\text { carbon fiber bicycles and aluminum alloy } \\
\text { bicycles. }\end{array}$ & $\begin{array}{l}\text { It supported brand construction through technical } \\
\text { development. }\end{array}$ \\
\hline & 1992 & Started investments in China. & $\begin{array}{l}\text { It expanded in potential markets and lowered its } \\
\text { production costs. }\end{array}$ \\
\hline & 1998 & Invested in Hodaka of Japan. & \\
\hline & 2000 & $\begin{array}{l}\text { Founded the first life experience store } \\
\text { under direct management. }\end{array}$ & $\begin{array}{l}\text { By operating a direct sales store, it demonstrated a } \\
\text { consumer-oriented culture and reproduced this } \\
\text { experience in the operation of following stores. }\end{array}$ \\
\hline & 2001 & $\begin{array}{l}\text { Awarded by Forbes as a global top } 20 \\
\text { small-scale enterprise. }\end{array}$ & \\
\hline \multirow{8}{*}{$\begin{array}{l}\text { Brand growth } \\
\text { stage } \\
\text { 2002-present }\end{array}$} & 2002 & $\begin{array}{l}\text { To combat low-price competition from } \\
\text { China and countries in Southeast Asia, } \\
\text { Giant recruited bicycle suppliers in } \\
\text { Taiwan to found an industrial alliance } \\
\text { called the A-team, to create bicycles with } \\
\text { high additional value. }\end{array}$ & $\begin{array}{l}\text { It avoided cost competition with new markets, } \\
\text { developed industrial alliances, upgraded the overall } \\
\text { bicycle industry in Taiwan, and created the market for } \\
\text { high-value bicycles. }\end{array}$ \\
\hline & 2002 & $\begin{array}{l}\text { Sponsored professional bicycle teams in } \\
\text { Europe. }\end{array}$ & $\begin{array}{l}\text { By implementing sports marketing, and through the } \\
\text { feedback from professional bicycle riders, it enhanced } \\
\text { its techniques. }\end{array}$ \\
\hline & 2004 & $\begin{array}{l}\text { German T-Mobile won the grand } \\
\text { championship of the Tour de France } \\
\text { riding a carbon fiber bicycle produced by } \\
\text { Giant. }\end{array}$ & \\
\hline & 2006 & $\begin{array}{l}\text { Formed a brand reconstruction team and } \\
\text { invited Interbrand to be the consultant. }\end{array}$ & $\begin{array}{l}\text { By cooperating with the consulting companies of } \\
\text { foreign brands, it reconstructed the brand thinking of } \\
\text { international market. }\end{array}$ \\
\hline & 2007 & $\begin{array}{l}\text { King Liu, the founder and president of } \\
\text { Giant, toured Taiwan by bicycle at the } \\
\text { age of } 73 \text {. }\end{array}$ & It created the biking culture. \\
\hline & 2008 & $\begin{array}{l}\text { Founded the first female bicycle store in } \\
\text { the world. }\end{array}$ & It enhanced the segmentation of different markets. \\
\hline & 2009 & Expanded to bicycle travel. & Diversified operations \\
\hline & 2011 & $\begin{array}{l}\text { Held "Taiwan rolling forward," an } \\
\text { activity marking the one hundredth } \\
\text { anniversary of Taiwan. More than } \\
110,000 \text { people across Taiwan rode } \\
\text { bicycles at the same time, breaking the } \\
\text { Guinness World Record. }\end{array}$ & $\begin{array}{l}\text { In the Taiwan market, it enhanced biking culture. By } \\
\text { constructing bicycle-friendly environments and life } \\
\text { attitudes in Taiwan, it established a market with } \\
\text { national competitive advantages. }\end{array}$ \\
\hline
\end{tabular}




\section{LESSONS LEARNED FROM GIANT}

1) For suppliers in newly industrialized countries, learning from international OEM alliances is an important channel of corporate growth. However, the key for sustainable operations is the business owners' continuous investment in R\&D to enhance the core capacity. In the beginning, Giant was an OEM supplier for Schwinn, and through this it learned the basic techniques to manufacture bicycles and obtained important business revenues. However, OEM has both advantages and disadvantages. It helps the growth of suppliers in newly industrialized countries. However, when foreign clients acquire other low-cost labor sources and immediately withdraw their orders, OEMs will encounter significant operational crises. Giant serves a great example. After it learned the basic knowledge of bicycles during the OEM process, it started cooperating with external academic institutes and the Industrial Technology Research Institute to develop carbon fiber bicycles, develop differentiated manufacturing techniques, and promote products with its own brand. Because of its brand, Giant survived when Schwinn, which represented $75 \%$ of Giant's business revenue, changed its orders to China.

2) Small and medium enterprises should be actively internationalized to find the needs of consumers in different areas, as the feedback of consumers in different markets can be used to enhance their techniques. According to the author's interview with Giant, sponsorship of international bicycle teams can not only expose the brand but also be helpful to upgrade the company's core technical capacity. In addition, consumers in developed countries have different needs for bicycles, in comparison to Taiwanese consumers. As regards to Giant, the riders' continuous practicing and demands for functions were new challenges for its R\&D personnel. By satisfying the riders' needs, Giant was able to upgrade its technical capacity.

3) Since competitive advantage based on low cost usually does not last for long, industrial upgrading is the solution for sustainability. Although Taiwan has been an important exporter of bicycles, at the end of the 1990's it gradually lost its competitiveness due to low-price advantages in China and Southeast Asia. Hence, Giant recruited component suppliers and its main rival Merida to form a bicycle industry alliance, called the A-team. Through this alliance, the members of the alliance disclosed the important product manufacturing techniques and upgraded the quality of MIT (made in Taiwan) bicycles. Therefore, MIT bicycles can be segmented from bicycle markets in low-cost countries.

4) Many enterprises starting as OEMs tend to have manufacturing and cost-oriented thoughts. However, only marketing and consumer oriented thoughts can lead to successful transformation of enterprises. Through sports marketing, Giant considerably enhanced its brand reputation. For instance, it sponsored the German T-Mobile teams which had several excellent performances in the Tour de France. When the riders won the championship, their Giant bicycles became the company's best marketing tool. Giant effectively changed the bicycle environment in the market of its home country (Taiwan) and consumers' concepts about bicycle. After the founder accomplished a bicycle tour around Taiwan at the age of 73, consumers in Taiwan not only treated bicycles as transportation and recreational tools, but also regarded them as the tool to explore Taiwan and fulfill self-realization. The brand value of Giant was thus enhanced. In addition, Giant developed the first bicycle store exclusively for female consumers. This business was expanded to include bicycle travel. Giant also constructed planning and sponsorship for bicycle-friendly environments in the cities of Taiwan. The marketing points were based on not only the functional appeal of the products, but also the biking culture.

\section{DISCUSSION QUESTIONS}

Overall, Giant presents a successful business story.

1. Can Giant's growth strategies apply to the bicycle industry of your country?

2. Can its growth strategies apply to other industries?

3. What do you think that how Giant can be stronger in the future? 


\section{AUTHOR INFORMATION}

Wei-Li Wu is an Assistant Professor at the Department of International Business at Chien Hsin University of Science and Technology. He received his PhD in International Business from the College of Management at National Chi Nan University in Nantou, Taiwan. His research interests include knowledge management, international business management, and organizational behavior. E-mail: wuweili0709@yahoo.com.tw

Yi-Chih Lee received her PhD in Business Administration from the Fu Jen Catholic University of Taipei, Taiwan. Currently, she is an Assistant Professor at the Department of International Business in Chien Hsin University of Science and Technology, Zhongli, Taiwan. Her research interests include health industry management, data mining, and customer relationship management. E-mail: 1yc6115@ms61.hinet.net (Corresponding author)

\section{REFERENCES}

1. Lin, C. Y. (2008). Legend of Giant: Global brand management of Giant. Taipei: Commonwealth Publishing.

2. Giant bicycles website. Retrieved 12 January 2014 from http://www.giant-bicycles.com/en-us/

3. 2012 Giant Manufacturing annual report. 


\section{NOTES}

